\title{
An Emerging Human Right to Security from Climate Change: The Case Against Gas Flaring in Nigeria
}

\author{
Amy Sinden*
}

\section{INTRODUCTION}

Is there a human right to security from climate change? A recent ruling by the Federal High Court of Nigeria suggests that there is. Royal Dutch/Shell Group (Shell) and the other companies that produce oil in Nigeria have engaged for decades in a practice called "gas flaring," in which natural gas released during oil extraction is burned off, discharging large clouds of greenhouse gases and other pollutants into the atmosphere. ${ }^{1}$ Citing the climatic and other environmental impacts of gas flaring on their community, Nigerians living near the flares filed a lawsuit charging that the practice violates their fundamental rights to life and dignity guaranteed under the Nigerian constitution. ${ }^{2}$ In a ruling on November 14, 2005, the Federal High Court of Nigeria agreed and ordered Shell and the Nigerian National Petroleum Corporation "to take immediate steps to stop the further flaring of gas" in the plaintiffs' community. ${ }^{3}$ Although the court's ruling thus far has had little practical

* Associate Professor, Temple University Beasley School of Law, 1719 N. Broad St., Philadelphia, PA 19122, Amy.Sinden@temple.edu, (215) 204-4969.

1 See The Climate Justice Programme \& Environmental Rights Action/Friends of the Earth Nigeria, Gas Flaring in Nigeria: A Human Rights, Environmental and Economic Monstrosity (2005) [hereinafter Gas Flaring Report], available at http://www.climatelaw.org/media/gas.flaring/ report/gas.flaring.in.nigeria.html; Asume (Isaac) Osuoka, The Shell Report: Continuing Abuses in Nigeria - Ten Years after Ken Saro Wiwa 23-26 (Environmental Rights Action/Friends of the Earth Nigeria 2005) (on file with author) [hereinafter Shell Report]. Gas flaring produces both of the primary greenhouse gases, carbon dioxide and methane. Gas Flaring Report, at 20; Intergovernmental Panel on Climate Change, Climate Change 2007: The Physical Science Basis, Summary for Policymakers 4-5 (Feb. 2007) [hereinafter IPCC 2007 Summary], available at http://www.ipcc.ch/SPM2febo7.pdf. Methane has twenty-one times the global warming impact of carbon dioxide. Most of the gas emitted in a flare is burned, producing carbon dioxide from the combustion process. But the combustion process is never 100 percent efficient. As a result, some methane gas - as much as 10 percent - is released directly into the atmosphere without combusting. See Gas Flaring Report, at 20.

2 See Gbemre v. Shell Petroleum Development Co., Suit No. FHC/CS/B/153/2005, Motion Ex Parte under Section $46(1)$ of the Constitution of the Federal Republic of Nigeria, Statement Pursuant to Order 1, Rule 2(3) of the Fundamental Rights (Enforcement Procedure) Rules, and Verifying Affidavit (July 11, 2005) [hereinafter Gbemre Pleadings], available at http://www.climatelaw.org/cases.

3 Gbemre v. Shell Petroleum Development Co., Suit No. FHC/CS/B/153/2005, Order (Nov. 14, 2005) [hereinafter Gbemre Order], available at http://www.climatelaw.org/cases. 
effect - the oil companies have yet to comply and are appealing the order - it opens up intriguing possibilities for crafting legal approaches to the problem of climate change.

Little analysis of the plaintiffs' climate change claim accompanied the Nigerian court's ruling, but the notion that actions that contribute substantially to climate change may violate fundamental constitutional or human rights is intuitively appealing. Constitutional rights and international human rights - I will refer to these collectively as "human rights" - invoke a sense of profundity and moral weight that comports with the enormity and gravity of the climate change problem. In my view, this intuition is correct. A right to security from climate change actually fits comfortably within the principles and values that underlie some of the oldest and most venerated rights in the civil and political rights tradition. Even though that tradition was born more than 200 years ago, long before anyone could have conceived of the idea that human activities might one day reach a magnitude and scope sufficient to alter the environment on a global scale, the problem of climate change - at least in its political aspects - is exactly the kind of problem that civil and political rights are aimed at combating. It is a problem that arises fundamentally from the distortion of government decision making by power.

Human rights, of course, have traditionally been defined as imposing duties primarily on States. ${ }^{5}$ And yet in many instances the affirmative acts that contribute most dramatically to climate change are committed by private actors, as Shell's involvement in the Nigerian gas flaring illustrates. While the Gbemre court did not address this issue, even under traditional doctrine, the close relationship between Shell and the Nigerian government in the operation of the Nigerian National Petroleum Corporation may well warrant a finding of liability against Shell for acting in concert with the State. Moreover, the recognition of rights in the context of climate change may help build momentum toward a reconceptualization of human rights law that broadens the set of duty holders to include not just States, but another set of important actors on the international stage that often wield even more wealth and power than States themselves - multinational corporations.

This chapter proceeds in two parts. The first part provides some background on oil development in the Niger Delta and the gas flaring litigation. The second part explores possible theories under which a right to security from climate change might be grounded in traditional civil and political human rights, as well as how such rights

Another action alleging human rights violations in connection with climate change has been filed with the Inter-American Commission on Human Rights by Inuit Circumpolar Conference against the United States. See Petition to the Inter-American Commission on Human Rights Seeking Relief from Violations Resulting from Global Warming Caused by Acts and Omissions of the United States (Dec. 7, 2005), available at http://www.ciel.org/Publications/ICC_Petition_7Deco5.pdf. For a discussion of that action, see Hari M. Osofsky, The Inuit Petition as a Bridge? Beyond Dialectics of Climate Change and Indigenous Peoples' Rights, in this volume.

4 See infra notes 57 to 60 and accompanying text.

5 See infra note 99. 
might be either traditionally applied or reconceptualized to impose liability on a private multinational corporation like Shell.

\section{BACKGROUND}

\subsection{Decades of Environmental Devastation and Military Repression in the Niger Delta}

Where the Niger River reaches the coastal plain on the south coast of West Africa, it divides into hundreds of small streams and rivulets branching out across the flat landscape. Covering 70,000 square kilometers, the Niger Delta is one of the largest wetlands on Earth. ${ }^{6}$ For millennia, it has supported a rich and diverse ecosystem, with one of the highest concentrations of biodiversity on the planet.7 It is also home to over 10 million people from dozens of different ethnic groups, most of whom depend on subsistence fishing and small-scale farming. ${ }^{8}$

However, the rich ecology of this region and its inhabitants' way of life are now in peril. In the 1950s, Shell and British Petroleum discovered oil in the Delta. ${ }^{9}$ Currently, 2.5 billion barrels of crude oil are pumped out of the Niger Delta each day. ${ }^{10}$ While a number of big multinational oil companies now have partial stakes in Nigeria's oil industry, Shell remains by far the biggest player. Nearly half of Nigeria's oil is produced by the Shell Petroleum Development Company, a joint venture operated by Shell and owned primarily by Shell and the Nigerian National Petroleum Corporation (NNPC). ${ }^{11}$ Oil dominates the Nigerian economy, providing more than 80 percent of government revenues, 90 percent of foreign exchange earnings, and 40 percent of GDP. ${ }^{12}$ Three-quarters of Nigeria's oil comes from the Niger Delta. ${ }^{13}$

6 Ibibia Lucky Worika, Deprivation, Despoliation and Destitution: Whither Environment and Human Rights in Nigeria's Niger Delta?, 8 ILSA J. INT'L \& Comp. L. 1, 4 (2001).

7 See Kaniye S. A. Ebeku, Biodiversity Conservation in Nigeria: An Appraisal of the Legal Regime in Relation to the Niger Delta Area of the Country, 16 J. EnvTL. L. 361, 362-65 (2004); Andy RowelL, James Marriott \& Lorne Stockman, The Next Gulf: London, Washington \& Oil Conflict in Nigeria 8 (2005); Ike Okonta \& Oronto Douglas, Where Vultures Feast: Shell, Human Rights and Oil in the Niger Delta 61-63 (2003).

8 Id.; Worika, supra note 6, at 4 .

9 Gas Flaring Report, supra note 1, at 6; Rowell, supra note 7, at 58.

10 Gas Flaring Report, supra note 1, at 5.

11 See Rowell, supra note 7, at 9-10. Shell owns a 30 percent share, NNPC a 55 percent share, the French company ELF-Aquitaine a 10 percent share, and the Italian company AGIP a 5 percent share. See Okonta, supra note 7, at 49. Under the Nigerian Constitution, all oil is the property of the federal government, so all oil companies operate in Nigeria as joint ventures with the NNPC. See Constitution of the Federal Republic of Nigeria (1999), Art. 44(3); Alison Shinsato, Increasing the Accountability of Transnational Corporations for Environmental Harms: The Petroleum Industry in Nigeria, 4 Nw. U. J. InT'L Hum. Rights 186, 191 (2005).

12 See Rowell, supra note 7 , at 9.

13 See OKonta, supra note 7 , at 18. 
Since Shell first struck oil there five decades ago, 159 oil fields and 275 flow stations have been carved out of the fragile Delta ecosystem. ${ }^{14}$ Seven thousand kilometers of rusty pipeline - some of it forty years old - snakes across the landscape. ${ }^{15}$ The pipeline frequently ruptures, spewing crude oil across the land and water. According to the Nigerian government, 6,817 oil spills occurred in the Niger Delta between 1976 and 2001 (about one a day for twenty-five years). But other experts estimate that the actual amount may be ten times higher. ${ }^{16}$ Even as of a decade ago, a report by the CIA estimated that the amount of oil spilled in the Niger Delta was already ten times the amount of the Alaskan Exxon Valdez spill. ${ }^{17}$

The spilled oil and the outdated waste disposal techniques practiced by Shell and the other oil companies operating in the Delta have wreaked havoc on the health of the people there and on the ecosystems upon which they depend. But spilled oil and waste is only part of the environmental devastation oil development has brought to the Delta. Oil deposits are often accompanied by natural gas that escapes from the ground when the oil is pumped. Although it is possible to capture this escaping gas and either reinject it into the ground or collect it for sale, the oil companies operating in Nigeria choose instead to simply burn it off. Indeed, gas flaring has been standard practice since oil production first began in Nigeria in the 1950 s. ${ }^{18}$ Thus, most of the oil wells in Nigeria are accompanied by a raging flame that burns twenty-four hours a day, reaching hundreds of feet into the sky, killing the surrounding vegetation with searing heat, emitting a deafening roar, and belching a cocktail of smoke, soot, and toxic chemicals into the air along with a potent mixture of greenhouse gases. ${ }^{19}$ The devastating environmental effects of this wasteful practice have led other countries to reduce gas flaring to a bare minimum. In the United States, less than half of 1 percent of extracted natural gas is flared; ${ }^{2 \circ}$ in Western Europe, the rate is less than 1 percent. ${ }^{21}$ But the same multinational corporations that have virtually stopped the practice in other parts of the world continue to flare 75 percent of the natural gas produced in Nigeria. ${ }^{22}$ Because the amount of oil drilling conducted in the Niger Delta is enormous - Nigeria is OPEC's fifth-largest producer of oil and most of it comes from the Delta ${ }^{23}$ - the absolute amount of gas being wasted by flaring and the magnitude of the accompanying environmental destruction is staggering. The Niger Delta produces 2.5 billion barrels of crude oil every day, and

14 See Tom O'Neill, Curse of the Black Gold: Hope and Betrayal in the Niger Delta, Nat'L GeOGRAPHIC, Feb. 2007, at 88, available at http://www7.nationalgeographic.com/ngm/o702/featurez/index.html.

15 See Shinsato supra note 11; see also ОкоnтA, supra note 7 , at $77-78$.

16 See O’Neill, supra note 14.

17 See Douglas Farah, Nigeria's Oil Exploitation Leaves Delta Poor, Poisoned, WAsh. Post, Mar. 18, 2001, at $\mathrm{A}_{22}$.

18 Shell Report, supra note 2, at 23-24; OKONTA, supra note 7, at 66.

19 Rowell, supra note 7 , at 67, 245; OKONTA, supra note 7 , at 73, 78-79, 84-85.

20 Shinsato, supra note 15 .

${ }^{21}$ See Peter Roderick, Environmental Justice, Climate Change, and Environmental Racism in the Níger Delta, available at http://www.foei.org/en/publications/link/env-rights/54.html.

22 See Gas Flaring Report, supra note 1, at 11.

23 See Shinsato, supra note 15, at 191. 
most of the associated 2.5 billion cubic feet of natural gas is burned off into the atmosphere. ${ }^{24}$ In 2001, 40 percent of all the natural gas burned throughout Africa was attributable to gas flaring in Nigeria. ${ }^{25}$ It is estimated that Nigeria's gas flaring has contributed more greenhouse gases to the atmosphere than all of sub-Saharan Africa combined. ${ }^{26}$

Ironically, the global climate change to which gas flaring in the Niger Delta makes such a significant contribution is likely to produce particularly devastating impacts in Nigeria itself. The Intergovernmental Panel on Climate Change (IPCC) has concluded that "Africa is one of the most vulnerable continents to climate variability and change." ${ }^{27}$ The Niger Delta itself is particularly vulnerable to sea level rise. The low-lying marshy lands of the Delta have been gradually subsiding in recent years, a process that has been significantly exacerbated by oil and gas extraction. ${ }^{28}$ This subsidence in combination with the sea level rise predicted to occur as a consequence of climate change is likely to cause widespread inundation and dislocation. Studies have estimated that a forty-kilometer-wide strip of the Delta could be inundated within decades and that 80 percent of the Delta's population will have to move. ${ }^{29}$ The IPCC reported in 2001 that a one-meter rise in sea level could put 600 square kilometers of land and more than 3 million people at risk in Nigeria. ${ }^{30}$ Additionally, increasingly frequent and severe storms triggered by climate change could have devastating impacts. One study concludes that rising sea surface temperatures off Nigeria's coast have the capacity to trigger tornado-type storms in the Niger Delta. Such storms are likely to cause "huge storm surges and catastrophic flooding that will result in unprecedented deaths and collapse or destruction of coastal infrastructure." ${ }^{31}$

Although the dangers of climate change have only recently come to be widely recognized, the people of the Niger Delta have long understood the devastating impacts of the oil industry on their lands and waters. Beginning in the late 1980s, protests against the oil industry in the communities of the Niger Delta met with

24 Gas Flaring Report, supra note 1, at 4-5.

25 Id.

26 Id.

27 IPCC, Climate Change 2007: Climate Change Impacts, Adaptation and Vulnerability, Summary for Policymakers 10 (Apr. 6, 2007) [hereinafter IPCC 2007 Impacts Summary], available at http://www.ipcc.ch/SPM6avro7.pdf. The enumerated impacts include the risk of regional conflict over dwindling water resources, declines in agricultural production, potentially irreversible losses in natural resource productivity and biodiversity, risks of increased vector- and water-borne disease, increased desertification, and flooding of coastal areas due to sea level rise. Id.

28 See RowelL, supra note 7 , at 235 .

29 Id.

30 See Intergovernmental Panel on Climate Change, IPCC Special Report on the Regional Impacts of Climate Change: An Assessment of Vulnerability, ch. 2.3.4.1.2, (1997) [hereinafter IPCC Special Report on Regional Impacts] available at http:/www.grida.no/climate/ipcc/regional/index.htm.

${ }^{31}$ D. O. Adefolalu \& J. F. Adeyemi, Climate Change: Potential Impact on the Niger Delta-the Economic Nerve-Center of Nigeria, International Conference on Energy, Environment and Disasters, Charlotte, N.C., July 24-30, 2005. 
increasingly brutal and violent repression by the Nigerian military. ${ }^{22}$ In the early 1990 in the Ogoniland region of the Niger Delta, Nigerian security forces killed 2,000 people and razed thirty villages in an attempt to quell mounting protests by the Ogoni people against oil development in their region. 33 There is evidence that Shell played a major role in instigating and supporting this violence, supplying helicopters and boats to transport the troops for these operations and paying bonuses to the military personnel who participated. ${ }^{34}$ There is also evidence that Shell was involved or complicit in the Nigerian government's 1994 arrest and subsequent execution of Ogoni political leader Ken Saro Wiwa in what was widely condemned as a sham proceeding. ${ }^{35}$

\subsection{The Gas Flaring Litigation}

The events described previously received considerable publicity and triggered two lawsuits alleging human rights violations in connection with the repression of the Ogoni and the environmental destruction caused by oil development in Ogoniland. ${ }^{6}$ But a series of lawsuits filed in 2005 in the Nigerian courts are the first to focus specifically on the practice of gas flaring in the Niger Delta. Seven cases have been filed in various local divisions of the federal court system in Nigeria. ${ }^{37}$ In each

32 See Rowell, supra note 7, at 83-84. In 1987, Nigeria's Military Police Force came to the small fishing village of Ito at the request of Shell to quell protests, arriving in speedboats belonging to Shell. By the end of the ensuing confrontation, the police had killed two demonstrators and destroyed forty houses, leaving 350 villagers homeless. Id.

33 See Paul Lewis, Blood and Oil: A Special Report: After Nigeria Represses, Shell Defends Its Record, N.Y. Times, Feb. 13, 1996, at A1.

34 See Douglass Cassel, Corporate Initiatives: A Second Human Rights Revolution?, 19 Fordham InT'L L.J. 1963, 1965-66 (1996).

35 See Paul Lewis, Blood and Oil: A Special Report: After Nigeria Represses, Shell Defends Its Record, N.Y. Times, Feb. 13, 1996, at Al; Douglass Cassel, Corporate Initiatives: A Second Human Rights Revolution?, 19 Fordham InT'L L.J. 1963, 1966-67 (1996); Rowell, supra note 7, at 1-7. Two prosecution witnesses recanted their testimony during the trial, claiming they had been bribed to provide testimony implicating Saro Wiwa in the murders. In a filmed statement and sworn affidavit, one said that he had been promised money and contracts with Shell to testify against Saro Wiwa and that Shell representatives were present when the offer was made. Shell Denies Foul Play in Nigerian Murder Trial, Guardian, Sept. 29, 1995, at 13 .

${ }^{6}$ One, filed in U.S. federal court in 1996 under the Alien Tort Claims Act against Shell, is still proceeding in the trial court. See Wiwa v. Royal Dutch Petroleum Co., 226 F.3d 88 (2d Cir. 2000). The other, filed against the Nigerian government before the African Commission on Human and Peoples' Rights, resulted in a ruling that the environmental destruction of Ogoniland and the military repression of the Ogoni people violated their rights to life, to nondiscrimination, to property and family, to health and a satisfactory environment, and to the free disposal of wealth and natural resources under the African Charter on Human and Peoples' Rights. See Social \& Econ. Rights Action Ctr. for Econ. and Social Rights v. Nigeria, African Commission on Human and People's Rights, Comm. No. 155/96 (2001), available at http://www1.umn.edu/humanrts/africa/comcases/155-96b.html; see also Justice C. Nwobike, The African Commission on Human and People's Rights and the Demystification of Second and Third Generation Rights under the African Charter: Social and Economic Rights Action Center (SERAC) and the Center for Economic and Social Rights (CESR) v. Nigeria, I AfriCAN J. LEGAL STUD. 129 (2005) (analyzing decision).

37 Conversation with Peter Roderick, Climate Justice Programme, July 28, 2006. 
one, the members of the local community as a class have sued the oil companies engaged in gas flaring in their locality. Four of the cases name Shell as a defendant. Chevron, the French company ELF-Aquitaine, and the Italian company AGIP are also each named in one of the other suits. Each suit also names as defendants the Attorney General of Nigeria and the Nigerian National Petroleum Corporation.

In each case, the plaintiffs allege that the defendants' practice of gas flaring violates their fundamental rights to life and dignity guaranteed under the Nigerian constitution as well as their rights to life, integrity of the person, health, and a satisfactory environment guaranteed under the African Charter on Human and Peoples' Rights..$^{8}$ The basis for these claims is the damage to the environment and the health of the local people caused by the air pollution and noise emitted by the flares: Plaintiffs point to an "increased risk of premature death, respiratory illnesses, asthma and cancer," acid rain, and reduced crop production. ${ }^{39}$ But perhaps most interestingly, plaintiffs also cite the contribution of gas flaring to climate change as a basis for their constitutional and human rights claims..$^{\circ}$

The first case was filed in the federal court in Benin City on July 11, 2005, by Jonah Gbemre on behalf of himself and the Iwherekan Community in Delta State (the "applicants").4' It named Shell, the NNPC, and the Attorney General of Nigeria as respondents. ${ }^{42}$ In their "counter-affidavits" to Gbemre's claims, Shell and NNPC denied that they engaged in gas flaring in the Iwherekan Community and denied any causal connection between their activities and the adverse environmental impacts cited by the applicants. ${ }^{43}$ Shell and NNPC then engaged in a series of procedural maneuvers apparently designed to delay a decision on the merits, but that instead seemed only to irritate the trial judge.

When their attempt to convince the trial judge to delay a ruling on the merits in order to dispose of certain procedural motions failed, the lawyers representing Shell and NNPC initiated multiple proceedings in the court of appeals. They then made repeated motions before the trial court for stays pending appeal. The trial judge denied these motions and repeatedly directed defense counsel to present argument in response to the merits of plaintiffs' claims. At each successive hearing, however, defense counsel avoided arguing the merits by making additional motions for stays, continuances, and even recusal, all of which the judge denied. At one hearing, relations between defense counsel and the judge became so strained that defense

$3^{8}$ Gbemre Pleadings, supra note 2, Statement at B.2, C.1, C.2.

39 Id., Verifying Affidavit at $11(\mathrm{~b}),(\mathrm{f}),(\mathrm{g})$.

$4 \circ \mathrm{Id}$. at $11(\mathrm{a}),(\mathrm{c})$.

${ }^{41}$ See Gbemre Pleadings, supra note 2. The court granted Mr. Gbemre permission to bring his case on July 21, 2005. See Gbemre v. Shell Petroleum Dev. Co., Suit No. FHC/CS/B/153/2005, Judgment 1 (Nov. 14, 2005) [hereinafter Gbemre Judgment], available at http://www.climatelaw.org/cases.

42 Gbemre Pleadings, supra note 2.

43 See Gbemre v. Shell Petroleum Dev. Co., Suit No. FHC/CS/B/153/2005, Counter Affidavit of Mrs. Enobong Ozor (Aug. 30, 2005); Gbemre v. Shell Petroleum Dev. Co., Suit No. FHC/CS/B/153/ 2005, Counter Affidavit for 2nd Defendant by Mary Akujobi (Sept. 15, 2005) [on file with author]. 
counsel abruptly stood up and, with all his junior associates in tow, walked out of court "without," in the words of the court, "the usual courtesy of bowing to the bench." 44

The trial judge's growing irritation with these maneuverings comes through in the final judgment, in which he accuses the lawyers for Shell and NNPC of acting "in bad faith" and calls their repeated motions for stays "an abuse of the process of this Court." 45 Ultimately, the court ruled that Shell and NNPC were "hereby foreclosed from presenting any further Reply" to the applicants' claims, ${ }^{46}$ and on November 14, 2005, the court issued its final judgment.

The court ruled that the constitutional rights cited by plaintiffs "inevitably include[] the rights to [a] clean poison-free healthy environment," and that the defendants' gas flaring constitutes "a gross violation of [the plaintiffs'] fundamental [constitutional] right to life and dignity." 47 While the court's judgment referenced the plaintiffs' assertions in their affidavit that gas flaring leads to the emission of greenhouse gases and "contributes to adverse climate change," 48 the court made no specific findings with respect to climate change and offered no analysis of whether the climate change impacts of gas flaring in particular formed part of the basis for its holding that a violation of constitutional rights had occurred. The court's order "restrained [Shell and NNPC] from further flaring of gas in Applicant's Community" and ordered those defendants "to take immediate steps to stop the further flaring of gas." 49

After the court's order, the flares continued to burn. The companies took no steps to stop gas flaring as they had been directed to do by the court and provided no indication that they intended to do so. In December 2005, the applicants went back to the trial court with a motion seeking to have certain officials of Shell and NNPC held in contempt..$^{\circ}$ When the court ruled on this motion it softened its original order somewhat, giving the defendants an additional year, until April 2007, to stop the flaring. But the judge also ordered officials of Shell and NNPC to personally appear before the court on May 31, 2006, to present a quarterly program for ending the flaring by the April 2007 deadline. ${ }^{51}$ That hearing never occurred, however. Shortly after the trial court's ruling, Shell and NNPC's repeated attempts to get the appeals court involved in the case finally bore fruit. The appeals courts actually issued an order restraining the trial court from sitting on May 31, 2006, thus halting the contempt proceedings. ${ }^{52}$ Subsequently, the trial judge was

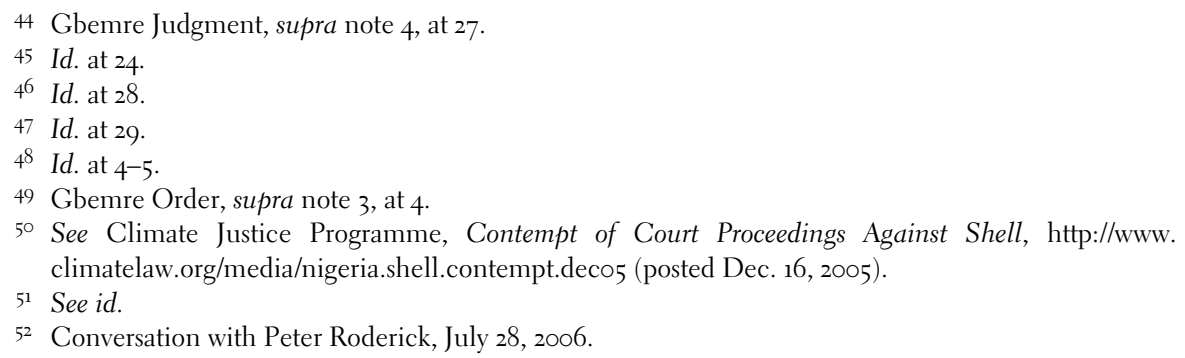


removed from the case and transferred to a different district in the north of the country. ${ }^{53}$

The April 2007 deadline has now come and gone, but Shell and NNPC have not stopped the flaring, nor have they submitted a plan for doing so. ${ }^{54}$ Meanwhile, the procedural issues as well as Shell's and NNPC's appeal of the trial court's ruling on the merits are in front of the court of appeal and a ruling is expected some time this year. The case will then likely make its way to the Nigerian Supreme Court. Thus, as a legal matter, the trial court's ruling stands, though it has had little practical effect.

While the trial court's judgment in Gbemre contains broad and definitive language reading an environmental right into the Nigerian Constitution's right to life, it does not explicitly analyze the question of whether and under what circumstances climate change impacts can provide a basis for finding a violation of that right. The sparseness of the court's analysis may reflect the fact that the respondents defended the case almost entirely on procedural grounds and presented little to the court in the way of substantive opposition to the applicants' claims. Nonetheless, the court's judgment does make reference to the evidence submitted by the applicants linking gas flaring to greenhouse gas emissions and climate change. 55 On that basis, one could read it as implicitly recognizing a right to security from climate change. Under any reading, though, the court's opinion leaves a lot of questions about the justifications for and scope of such a right unaddressed. The following analysis begins to explore these questions.

\section{LOCATING A RIGHT TO SECURITY FROM CLIMATE CHANGE IN THE HUMAN RIGHTS TRADITION}

\subsection{The Human Rights Tradition}

While there are clearly important distinctions between domestic constitutional rights and international human rights, for purposes of this analysis, the similarities are more important than the differences. ${ }^{56}$ Both constitutional rights and international human rights are traditionally understood to encompass a particular set of rights that individuals enjoy against the State. ${ }^{57}$ As such, they are fundamentally different

53 See Friends of the Earth, Shell Fails to Obey Gas Flaring Court Order (May 2, 2007), available at http://www.foe.co.uk/resource/press_releases/shell_fails_to_obey_gas_fl_02052007.html.

54 See id.

55 See supra note 48.

$5^{6}$ Constitutional rights and international human rights obviously differ in important respects. See generally Gerald L. Neuman, Human Rights and Constitutional Rights: Harmony and Dissonance, ${ }_{5} 5$ STAN. L. REv. 1863 (2003). International human rights, for example, stand even more firmly outside the State than do constitutional rights, since they are defined by international law and have the capacity to be enforced by international rather than domestic tribunals.

57 See Rex Martin, Human Rights and Civil Rights, in The Philosophy of Human Rights 75, 79-81 (Morton E. Winston ed., 1989). 
from the private rights of tort and contract that government enables individuals to enforce against each other. ${ }^{8}$ Constitutional and international human rights come into play when for some reason we cannot trust the political system to protect certain individual interests through the usual forms of private law. Usually that occurs when there is some reason to worry about abuse of power by the State itself. In those instances, because we cannot trust the State to police itself, we need some higher source of authority to act as a check on State power. Within domestic legal systems, that higher source of authority is the constitution. ${ }^{59}$ In international law, it is international human rights norms. ${ }^{60}$ Accordingly, both constitutional rights and international human rights share this key characteristic of standing outside and above the State in order to constrain abuses of State power. ${ }^{61}$ I use the term "human rights" to refer to both kinds of rights.

Human rights have evolved roughly in three waves. Civil and political human rights arose during the Enlightenment and form the basis for the U.S. Bill of Rights and the French Declaration of the Rights of Man. They are rooted in a conception of the person as an autonomous individual, and they stress the protection of individual dignity and autonomy from government interference. Economic and social rights, by contrast, arose in the mid-twentieth century and are grounded in the notion that government has affirmative obligations to protect individuals from deprivation of the basic material necessities of life. ${ }^{62}$ Finally, in the last several decades, a "third generation" of human rights has begun to emerge. These rights attach to groups rather than individuals and are aimed at the preservation of cultural identity and self-determination. ${ }^{63}$

Second and third generation rights may seem at first blush more amenable to the accommodation of a climate change right. Economic and social rights typically include a right to health and sometimes even an explicit right to a healthy environment, ${ }^{64}$ and third generation rights often include a right to the free use of natural resources. But second and third generation rights are generally less enforceable

$5^{8}$ See Locke: Two Treatises of Government 271-72, 357-63 (Peter Laslett ed., 1988) (government's purpose to protect rights of individuals against invasion by each other, but in serving that function, government necessarily accrues power, which it has duty to citizens not to abuse).

59 See, e.g., Stanley v. Illinois, 405 U.S. 645, 656 (1972) (observing that the Bill of Rights was "designed to protect the fragile values of a vulnerable citizenry" from overbearing government officials); Wolff v. McDonnell, 418 U.S. 539, 558 (1974) ("The touchstone of due process is protection of the individual against arbitrary action of government.").

6o See Steven Ratner, Corporations and Human Rights: A Theory of Legal Responsibility, 111 YALE L.J. 443, 466 (2001); Louis Henkin, International Rights as Human Rights, in The Philosophy of Human Rights 129, 131 (Morton E. Winston ed., 1989).

61 See Tom Campbell, Rights: A Critical Introduction 37-39 (2006).

62 See The Philosophy of Human Rights 4-5, 18-19 (Morton E. Winston ed., 1989); Campbell, supra note 61 , at 5-10.

${ }_{3}$ See generally Philip Alston, A Third Generation of Solidarity Rights: Progressive Development or Obfuscation of International Human Rights Law? 29 Neth. INT'L L. Rev. 307 (1982).

${ }^{64}$ See 1988 Protocol to the American Convention on Human Rights, Art. 11 ("Everyone shall have the right to live in a healthy environment"). 
than civil and political rights. ${ }^{65}$ First, they are typically expressed in less binding terms. For example, the International Covenant on Economic, Social, and Cultural Rights only calls on States to "take steps" to achieve the enumerated rights "up to the maximum of available resources." The International Covenant on Civil and Political Rights, by contrast, directs each State to "undertake to respect and to ensure [the enumerated rights] to every individual within its territory." ${ }^{7}$ Moreover, second and third generation rights are often framed in explicitly nonjusticiable terms. Many constitutions, for example, include them in a separate section designated for nonjusticiable rights. ${ }^{68}$ Indeed, the Nigerian constitution includes an environmental rights provision, but it is in a separate section of the constitution that the courts have interpreted as nonjusticiable. ${ }^{69}$ For this reason, the applicants in Gbemre did not even cite the environmental rights clause in their pleadings. ${ }^{\circ}$ They did cite certain second and third generation rights from the African Charter on Human and Peoples' Rights, but rather than relying on these rights as the basis for a free-standing claim, they simply referenced them as "reinforce[ing]" the civil and political rights in the Nigerian constitution.

In sum, civil and political rights, with their centuries-old pedigree, enjoy far more acceptance and are far more likely to be viewed as enforceable by the courts than second and third generation rights. Accordingly, a climate change right is likely to be far more effective both rhetorically and legally if it is grounded in traditional civil and political rights.

Additionally, the values and concerns that underlie our civil and political rights tradition are of particular salience in the context of climate change. As I have argued elsewhere, civil and political rights are grounded fundamentally in concerns about power imbalance and its distorting effect on government decision making. Thus, many of the rights that we consider central to our civil and political rights tradition aim at counteracting the disparity of power between the State and the individual in

65 See Robin R. Churchill, Environmental Rights in Existing Human Rights Treaties, in Human Rights Approaches to Environmental Protection 89, 100 (Alan E. Boyle \& Michael R. Anderson eds. 1996) (calling the environmental rights provision in Article 11 of the 1988 Protocol to the American Convention on Human Rights "rather weak, since it requires party States essentially to do no more than what they feel able to do, in the light of their available resources").

66 International Covenant on Economic, Social and Cultural Rights, Art. 2(1).

67 International Covenant on Civil and Political Rights, Art. 2(1).

68 Barry E. Hill, Steve Wolfson \& Nicholas Targ, Human Rights and the Environment: A Synopsis and Some Predictions, 16 Geo. InT'L Envtl. L. Rev. 359, 381-82 (2004); Michael R. Anderson, Individual Rights to Environmental Protection in India, in Human Rights Approaches to Environmental Protection 199, 213-14 (Alan E. Boyle \& Michael R. Anderson eds., 1996) (discussing constitution of India).

69 The environmental provision states: "The state shall protect and improve the environment and safeguard the water, air and land, forest and wildlife of Nigeria." Constitution of the Federal Republic of Nigeria, Art. 20. It is contained in a chapter entitled "Fundamental Objectives and Directive Principles of State Policy" rather than the chapter entitled "Fundamental Rights," which contains civil and political rights including those on which the Gbemre applicants relied.

70 Conversation with Peter Roderick, Climate Justice Programme, July 28, 2006. 
criminal proceedings..$^{71}$ Similarly, the right to free speech is often justified on the ground that by allowing public criticism of government officials, it provides a crucial check on government power. ${ }^{2}$ And the equal protection guarantee was added to the U.S. Bill of Rights after the Civil War in response to what is perhaps the most extreme example of power imbalance in society - the institution of slavery. ${ }^{73}$ Indeed, Cass Sunstein argues that much of modern constitutional doctrine reflects "a single perception of the underlying evil: the distribution of resources or opportunities to one group rather than another solely because those benefited have exercised the raw power to obtain government assistance." 74 By acting as "trumps," civil and political rights aim to counteract that underlying evil by effectively putting a thumb on the scale in favor of the weaker party. ${ }^{75}$

In the context of climate change, there is an enormous power imbalance between the interests that stand to gain from climate change regulation and those that stand in the short run at least - to lose. Those who stand to lose are those who profit from the extraction and combustion of fossil fuels. These are some of the wealthiest and most powerful corporations in the world. Multinational oil companies and car manufacturers dominate the list of the top revenue-producing corporations in the world. Shell, for example, earned more than $\$ 25$ billion in profits in 2006, second only to Exxon Mobil..$^{7}$ The influence that these corporate giants wield over government decision making is undeniable even in the developed world. 77 But the power that a company like Shell exerts over a poor cash-strapped government like Nigeria, that derives more than 80 percent of its revenues from oil production, is monumental.

On the other side, those who stand to gain from climate change regulation are primarily individual people, like the people of the Niger Delta who will be inundated by rising seas and battered by increasingly severe storms as the Earth warms. These "gainers" from climate change regulation are large in number, disproportionately

${ }^{11}$ See United States v. Gouveia, 467 U.S. 180, 189 (1984) (right to counsel aimed at correcting the imbalance of power between the government and the accused); Miranda v. Arizona, $3_{84}$ U.S. 436 , 460 (1966) (right against self incrimination aimed at ensuring "the proper scope of governmental power over the citizen ... and maintaining a fair state-individual balance"); Susan Bandes, "We the People" and Our Enduring Values, 96 Mich. L. REv. 1376, 1389, 1391 (1998) (arguing that the criminal procedure amendments "serve to address the inequality of power between the government and the individual and the need to curtail abuse of that power.").

72 See Vincent Blasi, The Checking Value in First Amendment Theory, Am. B. Found. Res. J. 521 (1977).

73 Since then, the Equal Protection Clause has been interpreted to address the subordination of other stigmatized groups as well. See Ruth Colker, Anti-Subordination Above All: Sex, Race, and Equal Protection, 61 N.Y.U. L. Rev. 1003, 1007 (1986); Owen M. Fiss, Groups and the Equal Protection Clause, 5 Phil. \& Pub. Aff. 107, 154-55 (1976).

74 Cass R. Sunstein, Interest Groups in American Public Law, 38 Stan. L. Rev. 29, 50-51 (1985).

75 See Ronald Dworkin, Taking Rights Seriously 234-35, 184-205 (1977).

${ }_{76}$ Terry Macalister, Exxon and Shell See Profits Rocket, Guardian Unlimited, Feb. 1, 2007, available at http://business.guardian.co.uk/story/o,2003392,00.html.

77 See Richard B. Stewart, Pyramids of Sacrifice? Problems of Federalism in Mandating State Implementation of National Environmental Policy, 86 YALE L.J. 1196, 1213 (1977). 
poor, ${ }^{78}$ widely dispersed, and have interests that are often hard to measure in precise economic terms and not likely to be felt until well into the future. In contrast to the oil companies, this is just the kind of group that has a particularly hard time organizing politically. ${ }^{79}$

This kind of power imbalance has the capacity to grossly distort government decision making. Arguably, this is exactly what has happened in Nigeria, where the government has been unable to effectively regulate the widespread practice of gas flaring despite a long-standing recognition of its devastating environmental and health effects. This is precisely the kind of situation that human rights are intended to address. Indeed, the trial court's ruling is a classic, triumphal human rights story, in which the politically powerless communities of the Niger Delta use human rights to beat back the Goliath of corporate-backed government power. In the end, of course, fighting vast and well-entrenched power disparities is a difficult business, and the human rights tool is only as strong as the judiciary that enforces it. The impunity with which Shell and the NNPC have ignored the trial court's orders and their apparent ability to inspire the court system to take extraordinary measures to prevent the trial judge from issuing further rulings in the case is a testament to just how enormous and intractable this particular power imbalance has become. Even if the lawsuit does not ultimately result in an enforceable order ending gas flaring, however, framing this conflict as a human rights issue still serves an important rhetorical purpose by bringing into stark relief the power imbalance at its root.

\subsection{Security from Climate Change as a Civil and Political Right}

A number of decisions from international and domestic tribunals have already begun to find a basis for environmental rights in certain well-established civil and political rights, like the right to life, the right to privacy and family life, and the right to information. These precedents may also provide support for a right to security from climate change.

The right to life, dignity, and personal security (or some variant thereof) appears in every human rights document. It is, perhaps, the most fundamental of all human rights. A number of domestic and international tribunals have found this right implicated in the context of environmental harms. ${ }^{80}$ In a case brought by the Ogoni people against the Nigerian government, for example, the African Commission on

$7^{8}$ See Intergovernmental Panel on Climate Change, Climate Change 2001: Synthesis Report, Summary for Policymakers 12 (2001), available at http://www.grida.no/climate/ipcc_tar/vol_/english/oo5.htm.

79 See Mancur Olson, The Logic of Collective Action: Public Goods and the Theory of Groups 16-23 (1965).

8o See generally Hari M. Osofsky, Learning from Environmental Justice: A New Model for International Environmental Rights, 24 Stan. EnvTL. L.J. 71 (2005). In 1972, the Stockholm Declaration was the first international instrument to draw an explicit connection between environmental protection and the right to life: "Both aspects of man's environment, the natural and the man-made, are essential to his wellbeing and to the enjoyment of basic human rights - even the right to life itself." Declaration of the United Nations Conference on the Human Environment, 11 I.L.M. 1416 (1972). 
Human and Peoples' Rights held that the pollution and environmental degradation caused by oil production in the Niger Delta constituted a violation of the Ogoni's right to life under Article 4 of the Charter. ${ }^{81}$ Similarly, in a study on the human rights situation in Ecuador, the Inter-American Commission on Human Rights found that environmental degradation connected with oil development activities in that country violated the residents' right to life under the American Convention on Human Rights. ${ }^{82}$ In a case brought by Canadian citizens challenging a radioactive waste facility near their homes, the United Nations Human Rights Committee found that the case raised "serious issues" regarding the right to life under Article 6(1) of the International Covenant on Civil and Political Rights, even though it ultimately dismissed the case for failure to exhaust domestic remedies. ${ }^{83}$ Additionally, domestic courts in India, ${ }_{4}$ Columbia, and now Nigeria, have found enforceable rights to a clean environment under constitutional guarantees of the right to life. ${ }^{85}$

Thus, where plaintiffs can show they will suffer some risk of death or personal injury from the impacts of climate change, they may be able to claim a violation of the core civil and political rights to life, dignity, and personal security. ${ }^{86}$ These are the rights the plaintiffs relied on in Gbemre and in which the Nigerian court found a generic "right to a clean poison-free, pollution-free and healthy environment." ${ }^{87}$ The pleadings do not specifically describe any particular climate change impacts that would cause personal injury to the residents of the Niger Delta and thereby potentially violate this right. But, as discussed earlier, rising sea surface temperatures associated with climate change are expected to trigger increasingly severe storms in the Niger Delta. Especially in combination with the Delta's increasing vulnerability to flooding due to climate change-induced sea level rise, such storms could well result in personal injuries and loss of life..$^{88}$

${ }^{81}$ Social and Econ. Rights Action Ctr. for Econ. and Social Rights v. Nigeria, African Commission on Human and People's Rights, Comm. No. 155/96, 70 (2001), available at http://www1 .umn.edu/humanrts/africa/comcases/155-96b.html.

82 Inter-Am. C.H.R., Report on the Situation of Human Rights in Ecuador, OEA/Ser.L/V/II.96, doc. 10 rev. 1 (1997).

83 EHP v. Canada, Communication No. 67/1980, CCPR/C/17/D/67/1980 (U.N. Human Rights Comm. Oct. 27, 1982).

${ }^{8}$ See Charan Lal Sahu v. Union of India, AIR 1990 SC 1480, 717; Michael R. Anderson, Individual Rights to Environmental Protection in India, in Human Rights Approaches to Environmental Protection 199, 215-16 (Alan E. Boyle \& Michael R. Anderson eds., 1996).

85 Barry E. Hill, Steve Wolfson \& Nicholas Targ, Human Rights and the Environment: A Synopsis and Some Predictions, 16 Geo. Int'L EnvtL. L. Rev. 359, 382-87 (2004).

86 See Prue Taylor, An Ecological Approach to International Law: Responding to the ChalLenges of Climate Change 197-200 (1998).

${ }_{77}$ Gbemre Judgment, supra note 41, at 29. See id. at 19 (noting applicant's argument that right to life should be broadly construed as "not just [a right not] to have one's head cut or guillotined, but also ... [as] the right of a human being to have his organs function properly and to the enjoyment of all his faculties").

88 See supra notes 27 to 31 and accompanying text. 
Even where the injuries associated with climate change are not life threatening, they may violate the right to privacy and family life. ${ }^{89}$ The European Court of Human Rights (ECHR) has found this right violated where pollution prevents people from living in their homes. In Lopez-Ostra $v$. Spain, for example, pollution and fumes from a tannery waste treatment plant that the government allowed to operate without a license forced the plaintiffs to move from their homes. ${ }^{\circ}$ The court held that "severe environmental pollution may affect individuals' well-being and prevent them from enjoying their homes in such a way as to affect their private and family life adversely, without, however, seriously endangering their health." ${ }^{11}$ Similarly, in Guerra v. Italy, the ECHR found the Italian government violated the right to privacy and family life of residents living near a chemical factory by failing to provide them with information on the risks posed by the factory. ${ }^{92}$ Thus, under these precedents, if rising sea levels caused by climate change displace people from their homes even without causing them physical injury, the right to privacy and family life might well be violated.

Activities contributing to climate change may also implicate a right to information. The right to information is often contained in statutes requiring the preparation of environmental impact assessments, but it sometimes also appears in human rights instruments ${ }^{93}$ and is increasingly viewed as derivative of the long-standing and fundamental civil and political right to freedom of expression. ${ }^{94}$ While no explicit right to information appears in the Nigerian constitution, in Gbemre, the applicants made an effort to derive such a right from the right to life. They alleged that Shell's and NNPC's failure to prepare an environmental impact assessment violated Nigeria's Environmental Impact Assessment Act and “contributed to the

89 International Covenant on Civil and Political Rights, Art. 8(1).

90 20 EHRR 277, ECHR $16798 / 90$ (1994).

91 Id. at 51.

9226 EHRR 357, ECHR 14967/89 (1998). The African Commission on Human and Peoples' Rights also found a violation of the rights to property and family in connection with the destruction of Ogoni homes and villages and forced evictions perpetrated by the Nigerian military in retaliation for protests against the environmental harms caused by oil development. See Social and Econ. Rights Action Ctr. for Econ. and Social Rights v. Nigeria, African Commission on Human and People's Rights, Comm. No. 155/96, 61-66 (2001).

93 See International Covenant on Civil and Political Rights, Art. 19(2) (freedom of expression includes "freedom to seek, receive and impart information and ideas of all kinds"). The yet-to-be-ratified Charter of Fundamental Rights of the European Union also contains a right of access to European Parliament, Council, and Commission documents at Article 42. See Charter of Fundamental Rights of the European Union, Art. 42, 2000/C 364/o1, 2000 O.J., (C 364), available at http://www.europarl.europa.eu/charter/pdf/text_en.pdf.

94 See Patrick Birkinshaw, Freedom of Information and Openness: Fundamental Human Rights?, $5^{8}$ Admin. L. Rev. 177 (2006). In its Resolution of the General Assembly of December 14, 1946, the United Nations declared that "[f]reedom of information is a fundamental human right and is the touchstone for all freedoms to which the United Nations is consecrated.” G.A. Res. 59(I), at 95, U.N. Doc. A64 (Dec. 14, 1946). Many international environmental treaties and declarations also contain explicit provisions requiring governments to provide access to environmental information. See Alexandra Kiss, The Right to Conservation of the Environment, in Linking Human Rights \& ThE Environment 31, 33-36 (Romina Picolotti \& Jorge Daniel Taillant eds., 2003). 
violation of the Applicant's... fundamental rights to life and dignity" under the Nigerian Constitution. ${ }^{95}$

An explicit right to information appears in Article 10 of the European Convention on Human Rights and Fundamental Freedoms, but the European Court of Human Rights has construed this provision narrowly, as simply imposing a duty on the State not to interfere with efforts to obtain information from public or private entities willing to share it. ${ }^{96}$ This crabbed reading has been widely condemned and many commentators have argued that a broader interpretation of the right to information is more in keeping with foundational principles of democracy and open government. The right can easily be interpreted, for example, as creating an obligation on the part of government to release information about its own projects. An even broader but still reasonable interpretation would impose a duty on the government to both obtain and disseminate information on public and private projects that may impact the environment. 97

While it has the potential to be broadly applicable in a variety of contexts, the right to information is particularly important with respect to environmental harms, the causes of which are often not superficially apparent..$^{8}$ Understanding such causes frequently requires access to sophisticated scientific and technical information that may often be in the control of government or corporate officials. Ensuring public access to such information is thus crucial to the proper functioning of democratic processes. These concerns are particularly salient in the context of climate change, where the causal chain between the activities triggering the harm and the harm itself is extremely complex and nonintuitive.

In sum, there is a significant potential for existing civil and political rights to form the basis for a claim arising from climate change-induced harms. In particular, there is precedent finding the right to life, dignity, and personal security, the right to privacy and family life, the right to information, and a number of the other core rights implicated in the context of environmental harms. Such precedent may be persuasive in the context of a climate change claim.

\subsection{The State Action Problem}

Much of the activity around the world that is contributing most significantly to climate change is conducted by private actors, often multinational corporations. Indeed, gas flaring in Nigeria provides a case in point. Yet human rights have traditionally been understood as rights that individuals enjoy against governments,

95 Gbemre Pleadings, supra note 2, Statement at B.3.

$9^{6}$ See Leander v. Sweden, ECHR (1987); Guerra v. Italy, 26 EHRR 357, ECHR 14967/89 (1998).

97 See Kiss, supra note 94, at 33-36.

$9^{8}$ See Claudia Saladin, Public Participation in the Era of Globalization, in Linking Human Rights \& the Environment 57 (Romina Picolotti \& Jorge Daniel Taillant eds., 2003). 
not private actors. ${ }^{99}$ Certainly, the climate change-inducing activities of private parties can be constrained to some extent by the private law of tort and contract. But where the governments that define such private rights themselves face incentives to encourage the very activities that drive climate change, such private rights may be ineffective. Where that is so, can human rights of the sort alleged in Gbemre be invoked to constrain the actions of private parties directly?

The court in Gbemre did not explicitly address this issue but, depending on the circumstances, such direct liability against private corporate actors for their contributions to climate change may be possible. First, under existing doctrine in some jurisdictions, private actors can be held liable for human rights violations where they act in concert with State actors. Moreover, there has in recent years been an increasing chorus of voices in the academic literature calling for an extension of existing doctrine in order to impose human rights duties directly on multinational corporations even in the absence of concerted action. ${ }^{100}$

Under existing U.S. constitutional law ${ }^{101}$ and international human rights law as interpreted by U.S. courts, ${ }^{102}$ for example, a private actor can be held liable for violations of constitutional or international human rights where it acts in concert with State agents. The plaintiff must show that the private actor is a "willful participant in joint action with the State or its agents" in violating such rights, ${ }^{103}$ or that "there is a substantial degree of cooperative action between the State and the private actors

99 See Tom Campbell, Moral Dimensions of Human Rights, in Human Rights and the Moral Responsibilities of Corporate and Public Sector Organisations 14 (Tom Campbell \& Seamas Miller eds., 2004); Ratner, supra note 60, at 465-66. There are a few exceptions. Human rights against genocide, war crimes, and crimes against humanity have, since the aftermath of World War II, been enforceable against private individuals. See id. at 466-68; Kadic v. Karadzic, 70 F.3d 232, 239-44 (2d Cir. 1995); Convention on the Prevention and Punishment of the Crime of Genocide, Dec. 9, 1948, art. 4, S. Exec. Doc. O, 81-1 (1949) (“[P] ersons committing genocide shall be punished whether they are constitutionally responsible rulers, public officials, or private individuals.”).

100 See Ratner, supra note 6o; Campbell, supra note 99, at 11; Menno T. Kamminga, Holding Multinational Corporations Accountable for Human Rights Abuses: A Challenge for the EU, in THE EU AND Human Rights 553 (Philip Alston ed., 1999); Nicola Jagers, Corporate Human Rights Obligations: In Search of Accountability (2002); Rebecca M. Bratspies, "Organs of Society": A Plea for Human Rights Accountability for Transnational Business Enterprises and Other Business Entities, 13 Мich. St. J. Int'L L. 9 (2005); Amy Sinden, Power and Responsibility: Why Human Rights Should Address Corporate Wrongs, in The New Corporate Accountability: Corporate Social ResponSibility \& The LAW (Doreen McBarnet, Aurora Voiculescu \& Tom Campbell eds.) [forthcoming, Cambridge Univ. Press].

${ }^{101}$ Dennis v. Sparks, 449 U.S. 24, 27 (1980) (articulating standard for establishing violation of U.S. constitutional rights under 42 U.S.C. $\left.\int 1983\right)$.

102 See Kadic, 70 F.3d at 245 (adopting $\$ 1983$ "under color of law" test for establishing violation of international human rights law by private actor under Alien Tort Claims Act); see also Doe v. Unocal, 963 F. Supp. 880, 891 (C.D. Cal. 1997); Wiwa v. Royal Dutch Petroleum Co., No. 96 Civ. 8386, 2002 WL 319887, at*10 (S.D.N.Y. 2002) (quoting Dennis and Unocal). See generally Hari M. Osofsky, Environmental Human Rights under the Alien Tort Statute: Redress for Indigenous Victims of Multinational Corporations, 20 Suffolk Transnat'L L. Rev. 335 (1997).

103 Dennis, 449 U.S. at 27. 
in effecting the deprivation of rights." ${ }^{104}$ Such tests have not generally been applied by international human rights tribunals because the jurisdictional rules of those forums only permit suits against States, but Steven Ratner has argued that a similar test should be applied to hold corporations accountable where they act in concert with government agents to commit human rights violations. ${ }^{105}$

The plaintiffs in Gbemre should be able to make a strong showing that this test is met with respect to Shell. There is certainly good reason to believe that there has been a close relationship between Shell and the Nigerian government, at least in the past. Indeed, significant evidence exists that joint action between them has led to human rights violations. Although the allegations have yet to be proved in court, in the Alien Tort Claims Act suit against Shell for human rights violations connected with Ken Saro Wiwa's death, petitioners have successfully defeated a motion to dismiss in a U.S. district court in New York based on the "joint action" theory. ${ }^{106}$ While the acts that form the basis for that suit were committed by the Nigerian government itself, evidence indicates that Shell assisted in those efforts by helping to plan attacks against the Ogoni, providing financial and logistical support to the Nigerian military, and participating in bribing witnesses. The climate change claims alleged in Gbemre would arguably present an even clearer case of joint action. There, the culpable act is the flaring of gas, which like all oil development activities in Nigeria, is conducted as part of a joint venture between Shell and the NNPC. Since the legal entity that is conducting the gas flaring - the Shell Petroleum Development Company - is actually jointly owned by Shell and the Nigerian government, it is hard to imagine a clearer case of "joint action." 107

Not all climate change activities involve such joint ventures between government and private entities. But in a world in which a number of multinational corporations wield more wealth than many countries and the power of multinationals to affect the conditions of daily existence for individuals often rivals that of government, the notion that human rights norms impose duties only on State actors may be gradually losing traction. ${ }^{108}$ Indeed, multinationals often exercise considerable power over States themselves, particularly in the developing world, where cash-strapped, debt-ridden governments are desperate for the foreign investment that multinationals can bring. In this environment, the ability of domestic governments to regulate the activities of multinational corporations is significantly compromised, a situation that is frequently exacerbated by the fact that a multinational may be incorporated in a different country from the one in which it is conducting business. ${ }^{109}$ Thus, as stories of environmental atrocities committed by powerful multinational corporations unchecked by domestic regulation continue to emerge from various corners of

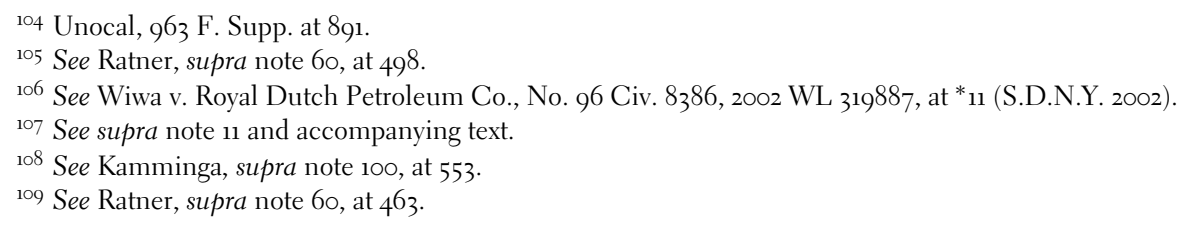


the globe, there have been increasing calls for the imposition of human rights duties directly on such corporations.

I have argued elsewhere that the same concerns that animated the conceptualization of civil and political rights in the eighteenth century as rights against government warrant the imposition of such rights directly against multinational corporations in the twenty-first century. ${ }^{110}$ Civil and political rights were grounded largely in concerns about power imbalances, and during the Enlightenment, when States were the largest aggregations of power in society, such rights were crafted to protect individuals from abuses of State power. But in today's world, where the power of multinational corporations rivals that of States, civil and political rights should protect against certain abuses of corporate power as well. Thus, I have argued that at least in situations in which multinationals are not checked by any domestic government and thus wield final unappealable power of the type that States traditionally wield, human rights duties should be imposed directly on those corporations. ${ }^{111}$ Indeed, gas flaring in Nigeria presents a classic example of a weak, cash-strapped government unable or unwilling to rein in corporate power. ${ }^{112}$ A series of feeble attempts by the Nigerian government to regulate gas flaring over the past several decades has been entirely ineffectual. ${ }^{113}$

In sum, while many of the actors contributing most significantly to climate change are private rather than State actors, even under traditional doctrine, such private actors may face human rights liability where they participate in joint action with the State. And even where such joint action cannot be shown, emerging theories of human rights eventually may justify the imposition of liability directly on multinational corporations, at least in situations in which they exercise State-like power.

\section{CONCLUSION}

Climate change may well be the most profound moral issue ever to confront the human species. While humans have altered their environment on a local scale probably for as long as they have walked the Earth, the impact of anthropogenic greenhouse gas emissions on the fundamental forces that drive the global climate system marks the first time that human activity can literally be said to have altered every spot on Earth. In the words of Bill McKibben, global climate change may indeed signal "the end of nature." ${ }^{114}$ Such a profound moral issue demands a profound response from law. Human rights, with all the gravity and moral weight they

110 See Sinden, supra note 100.

11 Arguably, this justification for the imposition of human rights duties on multinational corporations is even more salient in the context of climate change, where governments are disabled from regulating corporate behavior not only because of the inordinate power wielded by corporations themselves but because of the inescapable logic of the tragedy of the commons.

112 See Rowell, supra note 7, at 96-112.

113 The Associated Gas Reinjection Decree, enacted by the Nigerian government in 1979 was supposed to stop all flaring by 1984 but has had little or no effect. See OKONTA supra note 7 , at $73-74$.

114 Bill McKibben, The End of Nature (1989). 
have come to express, may well be an appropriate part of that response. The Gbemre case holds out hope that the recognition of a human right to security from climate change may provide a vehicle for courts to issue orders that begin to nudge those actors responsible for substantial greenhouse gas emissions toward more responsible behavior. And, just as importantly, Gbemre suggests how treating climate change as a human rights issue may serve to imbue it with a sense of gravity and moral urgency that has been too often missing from the public debate. 